\title{
THE SYNHALONIA OF CALIFORNIA.
}

BY CARROLL FOWLER, BERKELEY, CAL.

The material for this study was collected by Mr. H. O. Woodworth and myself during the spring and early summer of 1898. At Berkeley the collecting was carried on in a systematic manner, so that the number of each species taken gives a fair representation of their relative abundance. S. albicans and S. Edwardsii are the only species heretofore recorded from California. The species may be readily recognized by means of the following synopsis :

Abdomen with distinct, white bands.

Small, not more than .25 in. in length albieans

At least .40 in. in length.

Thorax with white pubescence, rather thin on disc californica, 9

Thorax with dense, reddish-brown pubescence speciosa, $q$.

Abdomen not distinctly banded.

Pale pubescence of the abdomen confined to the first segment.

Thorax with dense, brownish pubescence acerba.

Thorax with rather thin white pubescence albopilosa, $\delta^{\star}$

Pale pubescence extending more or less upon second abdominal segment.

Third joint of the antennæ shorter than the first.......Edwardsii, 0 .

Third joint as long as the first and second combined....intrudens, 0 .

1. Synhalonia albicans, Prov. San Gabriel, Cal. (H. O. Woodworth), June 23. Twelve specimens.

2. Synhalonia californica, n. sp.

$11 \mathrm{~mm}$. Clothed with ashy pubescence, abdomen white with bands.

o.--Head black, clothed with ashy pubescence; clypeus nude, coarsely punctured; antennæ entirely black. Thorax black, opaque, very finely punctured, clothed with ashy pubescence, a little thinner on the disc; tegulæ reddish-yellow; wings very slightly clouded; legs clothed with white pubescence, dense on posterior tibiæ and tarsi, more or less yellowish on tarsi beneath; apical points of tarsi brownish. Abdomen black, very finely punctured, narrow apical margins of the segments brownish; first segment clothed with ereet pale hairs, on base of second indistinct and sometimes wanting, and on apical margins of 2-5 a band of white appressed pubescence, brownish on middle of fifth Ventral segments fringed with white hairs.

Habitat.-Berkeley, Cal., May 1 and 9. Thirteen specimens. 
3. Synhalonia speciosa, Cress. Berkelev, Cal., April 26 to May 1. Two females. Previously recorded from Colorado.

4. Synhalonia acerba, Cress. $q$.

6.-Differs from $q$ in having the clypeus and labrum yellow, the antennæ reaching back to the second abdominal segment and crenulated toward tips (third joint is shorter than the first), and the legs clothed with pale pubescence. The pubescence of the thorax, as in some females, is strongly tinged with fulvous. The male is readily distinguished from Edwardsii by having no pale pubescence on the second abdominal segment.

Berkeley, Cal., six specimens; and San Mateo Co., Cal., two specimens. April and May. Collected upon Brassica campestris and Ranunculus californicus. Previously recorded from Nevada.

5. Synhalonia albopilosa, n. sp.

$13 \mathrm{~mm}$. Thorax small, clothed with white pubescence; abdomen large, oval.

o.-Head black, punctured, clothed with griseous pubescence, thin on clypeus; clypeus, except upper margin, and labrum, yellow: antennæ entirely black, reaching slightly beyond the second abdominal segment, crenulated toward tips, third joint shorter than first. Thorax black, finely punctured, not as broad as abdomen, clothed with rather long, white pubescence, not entirely concealing the surface; tegula black in front, brownish behind; wings hyaline; legs clothed with pale pubescence, apical joints of the tarsi brownish, intermediate tarsi long and slender. Abdomen oval, broader than the thorax, black, shining, finely punctured, apical margins of the segments pale brown; first segment with thin, erect white hair, 2-5 with short, thin, black pubescence, a very little white on the sides of the second, and that on 6-7 dark brown. Venter almost nude, otherwise as above.

Habitat.-Berkeley, Cal., April 18. One specimen, collected upon Ranunculus californicus.

6. Synhalonia Edwardsii, Cress. Berkeley, Cal., March 15 to May 9. Sixteen males, collected upon Brassica campestris, Ranunculus californicus, and Malvastrum capense, in botanic garden.

7. Synhalonia intrudens, Cress. Berkeley, Cal. March, fourteen males; and April 26, one male. Tulare, Cal. (H. O. Woodworth), May 10 three males. Collected chiefly upon Brassica campestris. Previously recorded from Nevada. 